\title{
The Interaction Of Three Dimensions Of Trust, Relational Selling, Team Selling And B2B Sales Success In The European Market
}

Richard A.L. Caldarola, Troy University, USA

\begin{abstract}
This study investigates the interaction of trust, relational selling behavior, team sales, and sales success in a business-to-business environment. The study data were collected in Europe for 270 different purchase situations for which business buyers rated their suppliers' salespersons on various dimensions. This research considers the relationships among three levels of trust and relational selling behaviors and measures the interaction of successful or unsuccessful selling environment, continuing purchase conditions for the buyers and the presence of team selling circumstances. The findings indicate that the three levels of trust are related positively, that successful salespersons are rated significantly higher by buyers for all three trust scales and for relational behavior. In addition, relational selling behavior is favored by buyers in repeat purchase conditions. Further results indicate limited interaction among trust and relational behavior in team selling conditions.
\end{abstract}

Keywords: Trust, relationship sales, team sales, sales success, B2B, repeat purchases

\section{INTRODUCTION}

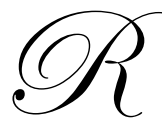

Celationship marketing has become one of the hottest fads in marketing over the last decade and its close cousin, relationship sales, is often recommended by sales consultants as a near panacea to customer retention. Yet relational behavior may or may not be related to actual sales performance, belying the promise of the Commitment-Trust theory of relationships proposed by Morgan and Hunt in 1994. Given the complexity of the sales function and the introduction of multiple environmental conditions and constraints, the old rules of interaction in the buyer-seller dyad have changed, and sales success is no longer guaranteed by merely showing up. Therefore, this study considers the interaction of trust, relational selling behavior, a team selling environment, and the likelihood of future purchase to more fully understand the implications of these critical categories in international sales performance.

\section{BACKGROUND AND PRIOR RESEARCH}

\section{Sales Success And Selling Performance}

Dwyer, Hill and Martin (2000) stated that sales success is dependent on the effectiveness of a salesperson's interactions with the buyer. Several other authors have found that sales success is directly attributable to the use of specific selling techniques applied during the selling process (Peterson, Cannito, and Brown 1995; Plank and Reid 1994; Predmore and Bonnice 1994; Spiro and Perreault 1979). Moreover, some selling techniques generate better sales results than others do (Dubinsky 1980; Dubinsky and Rudelius 1980; Hite and Bellizzi 1985). Wright and Lundstrom (2004) identified that the buyer's perceptions of the salesperson's employer and of the personal values and characteristics of the salesperson will influence the outcomes of the seller-buyer relationship. Sallee and Flaherty (2003) however defined sales performance as the manager's comparison of a salesperson's sales targets achievements to other salespeople in the company. 
Sales Performance for this study is limited to a Successful-Unsuccessful Salesperson dyad. The Successful Salesperson is one who received the business from the buyer, and the Unsuccessful Salesperson is the salesperson who did not receive the business, incorporating the measures applied by Plank, Reid, and Pullins (1999). However, this measure does not consider either the intention or likelihood of future purchases by the respondents.

\section{Trust}

In their early exploratory work, Walker, Churchill, and Ford (1979) proposed trust as an antecedent to other successful sales behaviors. Moorman, Zaltman, and Deshpande (1992) defined trust as the willingness to rely on an exchange partner. Notably, a breach of this trust may result in a lost customer. Others have defined trust alternatively as opportunistic behavior (Dwyer, Schurr, and Oh 1987), shared values (Morgan and Hunt 1994), mutual goals (Wilson 1995), making and keeping promises (Bitner 1995), uncertainty (Crosby, Evans and Cowles 1990), and actions with positive outcomes (Anderson and Narus 1984). Agarwal and Shankar (2003) separated trust into separate components of contract trust, the expectation that people will do what they say they are going to do, and self-disclosure trust, the willingness to share relevant information when appropriate.

However, although trust is considered to be a key element in relationship marketing, Crosby, Evans, and Cowles (1990) found that trust in the salesperson is unrelated to sales performance, and Chow, Reed, and Holden (1997) determined that buyers will not become loyal buyers of a company's product based only on trust of the salesperson. Similarly Doney and Cannon (1997) found that neither trust in the salesperson nor trust in the company by customers is related to purchase choice. However, Ekici and Sohi (2000) proposed that pre-relational trust is a predictor for supplier selection.

In his 1998 study, Selnes discovered that trust was the key variable when decisions are related to improving the scope of the business relationship, that satisfaction was the key variable when the issue is relationship continuity, and that customer satisfaction is an antecedent of trust. This suggests that the institutional buyers that Selnes studied must first experience the product and service quality before they trust the producers. Similarly, Bigne and Blesa (2003) found that trust improves a distributor's satisfaction with its relationship with its manufacturer.

For B2B buyers, trust in the salesperson is a significant antecedent to both attitude toward the company and to the product (Chow, Reed, and Holden 1997). To the contrary though, Foster and Cadogan (2000) found that trust between buyers and their salesperson does not necessarily imply buyers' trust in the firm. However, in a study of retail customers in Australia, Wong and Sohal (2002) found that salesperson trust is positively related to store trust; however, this may only be a reflection of service inseparability, in which the service provided by the salesperson (that instills trust in that salesperson) automatically is equated with trust in the store that is providing the retail service.

Characteristics of trust include how the salesperson represents the product, her/his company, and her/himself. This study uses the definitions applied originally by Plank, Reid, and Pullins (1999):

- $\quad$ Salesperson trust is the belief that the salesperson will fulfill his/her obligations as understood by the buyer.

- $\quad$ Product trust is the belief that the product / service will fulfill its functions as understood by the buyer.

- Company trust is the belief that the company will fulfill all its obligations as understood by the buyer.

\section{Relational Selling}

Relational selling behavior is defined as the nature of the salesperson's behavior during customer interactions. Parsons (2002) discovered that relational selling behaviors are generally positively related to relationship quality. There are also different levels of relational behaviors. Salespersons that have a greater commitment to customers will be perceived at a higher level than those who neglect customers. Further, the higher the level of this relationship status, the more likely the customer is to purchase additional services and products from the salesperson (Frankwick, Porter, and Crosby 2001). Relational selling is also determined by the age of the relationship. When the relationship is relatively new, how much the buyer likes the salesperson mediates the influence of frequency of personal interaction on trust (Nicholson, Compeau, and Sethi 2001). Ndubisi (2004) 
proposed that relationship selling will be more effective in low power distance cultures, collectivist cultures, feminine cultures, high uncertainty avoidance cultures, and long-term oriented cultures, and that high power distance, individualistic, masculine, low uncertainty avoidance, and short-term oriented cultures are more suitable for transactional sales. However, he did not propose measuring the mediating effect of culture on other environmental parameters. In a study of Italian Sales managers, Guenzi (2003) found that a sales manager's likelihood to prefer a relational approach does not increase with buyers' need heterogeneity or customization requests. These findings indicate that neither the difference in product offerings nor buyers' needs separately justify the use of either a relational or transactional approach.

Thus, relational selling behavior is the degree to which the salesperson demonstrates a willingness to establish and maintain a relationship compared to the indications of transaction-oriented behaviors. Relational behaviors include taking a problem-solving approach, telling the truth, not applying selling pressure, and having a customer orientation.

As suggested by Chow, Reed, and Holden, (1997) it can be estimated that B2B customers will not differentiate greatly between trust in the salesperson and trust in the company. Further, as implied by Selnes (1998), trust in the company will be related to trust in the product. Trust is also a central element in relational selling; one will naturally infer that there would be a positive relationship between perceptions of a salesperson who engages in more relational than transactional behavior and the degree of trust the buyer has in that salesperson (Frankwick, Porter, and Crosby 2001). As Wong's and Sohal's 2002 study findings suggest, trust in a salesperson may be indistinguishable from trust in the company; the buyer may see the two as synonymous. Gassenheimer and Manolis (2001) considered buyer dependence on the product to future purchase intentions, with trust in the salesperson and trust in the organization as mediating factors. Although they found that organization trust does not mediate the resource dependence on future intentions and that salesperson trust does, consistent measures of the association of product, organizational, and salesperson trust are notably absent in the literature. This study's first hypothesis therefore is:

$\mathbf{H}_{1}$ : $\quad$ Salesperson trust, product trust, company trust, and relational selling behavior are positively related to each other.

Walker, Churchill, and Ford (1979) proposed trust as an antecedent to other successful sales behaviors. Although Plank, Reid, and Pullins (1999) and later Pullins, Reid, and Plank (2004) found that successful sales persons were rated higher for trust factors by buyers than were unsuccessful sales persons, and a clearly positive outcome of trust is a successful sale (Anderson and Narus 1984), most other studies found that trust was unrelated to sales performance (Chow, Reed, and Holden 1997; Crosby, Evans, and Cowles 1990; Doney and Cannon 1997). Thus, following the propositions by Walker, Churchill, and Ford, and the findings from Plank, Reid, and Pullins, and later by Pullins, Reid, and Plank, the second hypothesis of this study holds that:

$\mathbf{H}_{2}$ : $\quad$ B2B buyers will rate Salesperson trust, product trust, company trust, and relational selling behavior significantly higher for Successful Salespersons than for Unsuccessful Salespersons.

\section{Repeat Purchases}

There is substantial research for repeat purchases in consumer products and services; one such finding suggested that repeat purchase behavior from the same supplier is dependent on the initial purchase satisfaction (Raymond and Tanner 1994). Several other recent similar studies have considered the consumer repeat purchase customer satisfaction relationship generally (Chandon, Morwitz, and Reinartz 2004; Fitzgibbon and White 2005; Patterson 2004; Skogland and Siguaw 2004; Tripp and Drea 2002). An extension of the consumer repeat purchase satisfaction literature is the investigation of the mediation of loyalty programs on repeat purchase intentions and behavior (Kim, Shi, and Srinivasan 2001; Meyer-Waarden 2007; Whyte 2002; Whyte 2004). Yet the literature on repeat business purchase behavior is limited in scope.

Kumar (2002) found that business customers' intent to repurchase depends not only on satisfaction with the supplier firm but with cost and competitor availability considerations as well. Similarly, there is limited research on 
the relationship between an industrial buyer's repeat purchase conditions and the degree of relationship selling behavior exhibited by the salesperson, although a six year old study did find that the higher the salespersoncustomer relationship status, the more likely the customer will be to purchase additional services from the salesperson in retail life insurance sales (Franwick, Porter and Crosby 2001).

It is notable though that firms with a long-term orientation attempt "to maximize their profits over a series of transactions [with their channel partner]" (Ganesan 1994, p. 3). As Ganesan noted further, the temporal duration of a relationship is likely to affect both parties' expectations that the relationship will continue. Furthermore, as Anderson and Weitz proposed (1989), adjustments are made to accommodate the expectation for a continued relationship. Similarly, Lusch and Brown (1996) found that the greater the long-term orientation of a wholesaledistributor toward its relationship with its supplier, the greater the development of relational behavior between the parties. Thus, it is proposed that:

$\mathbf{H}_{3}$ : $\quad$ Buyers of repeat purchase industrial products and services will prefer greater relational selling behavior from the salesperson than will buyers of one-time transaction industrial products and services.

\section{Team Selling}

As the importance of the transaction to the buyer increases, selling centers will have a greater degree of involvement with the buyer, will be more extensive, and engage in more frequent interactions (Moon and Armstrong 1994). Moreover, it would appear obvious that as customers and their product needs become more complex and more heterogeneous, it would be ever more important to have more specialists within the supplier's organization (Perry, Pearce, and Sims 1999). Similarly Jones, Dixon, Chonko and Cannon (2005) proposed that team selling to key accounts is more likely when there is a one time buy of a complex item, the potential sale is a relatively large one for the selling firm, and the product is new to the key account manager, although they did not distinguish the and-or relationship among these characteristics. However, in their study of German and U.S. firms, Workman, Homburg, and Jensen (2003) failed to find any statistically significant relationship between use of sales teams and key account management effectiveness.

It should hold though that the more that team selling is involved in an account, the more the buyer would trust the team; conversely the lower the percentage of team selling, the closer the buyer would be to the salesperson. Therefore the buyers' perceptions of salesperson trust and relational selling behavior would be inversely related to the degree of team selling. Furthermore as proposed in $\mathrm{H}_{1}$, buyers will tend to not differentiate among the three components of trust, leading to the fourth hypothesis:

$\mathbf{H}_{\mathbf{4}}$ : The greater the percentage of team sales, the lower B2B buyers will rate Salesperson trust, product trust, company trust, and relational selling behavior.

Although there are no prior studies that investigated the relationship between the buyers' anticipated future purchase conditions (one time only versus a repeatable purchase situation) and the effect of team sales, it may be deduced from Moon and Armstrong (1994) that greater involvement with customers that results from team sales will result in a closer association with repeat purchase buyers, and affect the buyers' perceptions of trust and of the individual salesperson's relational selling behaviors. Therefore, the final hypothesis of this study is:

H5: There is a significant interaction between repeat purchases and team sales for B2B buyers on Salesperson trust, product trust, company trust, and relational selling behavior.

\section{METHODOLOGY}

Two questionnaires based on the framework developed by Reid, Plank, and Minton (1996) were prepared; one asked the respondent to reply to questions about a Successful Salesperson, and the other for an Unsuccessful salesperson. The Successful Salesperson was defined for the respondents as a salesperson who received the business from the buyer, and the Unsuccessful Salesperson as a salesperson who did not receive the business. Key variables in the questionnaire included 
- $\quad$ Sales Performance - Successful or Unsuccessful

- $\quad$ Salesperson trust (10 questions), examples include

- Salesperson tells the truth

- I have good feelings when dealing with this salesperson

- Salesperson understood my feelings

- $\quad$ Product trust (5 questions), incorporated questions related to general confidence in the product:

- Product/service will give us little trouble in use

- Product/service will please those in our company who use it

- Product/service will do everything we want it to

- $\quad$ Company trust (5 questions), questions to gauge level of overall trust in the company the salesperson works for, such as

- Company can be counted on to do right by us

- Company has a good reputation

- Company will do what it takes to make us happy

- $\quad$ Relational behavior (8 questions), general customer orientation questions, including

- Salesperson tried to find out which products would be most helpful to me

○ Salesperson took a problem solving approach

- Salesperson was customer oriented

- $\quad$ Repeatable purchase: One time buy, or Repeat purchase

- $\quad$ Percent of team calls: $0,20,40,60,80$ or $100 \%$

700 questionnaires were distributed to Western European buyers of a global, business telecommunication products and services company. Thus, the company and product offerings were similar among all respondents. The questionnaire was written in English because both the sellers and buyers conduct sales transactions in English. Respondents were asked randomly to respond to either of the two questionnaires for a successful or unsuccessful salesperson. 270 completed, usable surveys, a 35\% participation rate, were returned over the 12-week survey period.

The salesperson, product, and company trust questions were measured on a 5 point scale, anchored at 1 for Strongly Agree and 5 for Strongly Disagree. The relational behavior questions were measured on a 7 point scale, with 7 for Strongly Agree and 1 for Strongly Disagree; three of the eight questions were reverse coded and were recoded prior to the subsequent analyses.

Reliability analyses were conducted for the trust and relational behavior variables. All of the alphas listed were above 0.80 (.92 for salesperson trust, .82 for product trust, .83 for company trust, and .81 for relational behavior), indicating that the scales provide internally consistent measures of the theoretical constructs and are reliable (Nunnally 1967). A confirmatory factor analysis was conducted for all four constructs. One factor was extracted for each variable; each factor accounted for more than $55 \%$ of the variance. A standardized regression score was retained as a new variable to reflect each of the extracted factors for salesperson trust, product trust, company trust, and relational behavior. These regression scores were used as inputs for subsequent analyses.

A Multivariate Analysis of Variance (MANOVA) using a $2 \times 2 \times 5$ factorial design was conducted. Dependent variables were the regression scores for salesperson trust, product trust, company trust, and relational behavior. The independent factors were Sales Performance (Successful or Unsuccessful), repeatable purchase, and percent of team calls.

\section{DISCUSSION OF RESULTS}

There were 147 questionnaires for Successful salespersons; the remaining 123 were for Unsuccessful salespersons. There were 83 one time buys and 187 repeatable purchases. 51 of the respondents had $60 \%$ or more in sales calls, although only 2 of the 270 in the sample had $100 \%$ team sales calls.

Three correlation analyses were conducted, one for all cases, one for only successful salespersons and one for only unsuccessful salespersons. As indicated in Tables 1 through 3, all of the trust factors and relational behavior were positively related (the relational behavior scale is reversed from the trust scales), supporting $\mathrm{H}_{1}$. In all three 
tests, the highest correlation coefficient was between company trust and product trust. One may infer that because the salesperson represents the company and its products, the buyer will tend to trust all three similarly. An industrial company cannot be easily distinguished from its products, better explaining the high correlation coefficients between company and product trust. However, relational behavior, although significantly positively related to all three trust variables, has a lower correlation coefficient than any other bivariate relationship. This indicates preliminarily that because the relational behaviors of accuracy, customer orientation, and other non-transactional approaches are not highly related to personal trust in the salesperson, relational behavior may also not be an antecedent of trust.

Table 1

Correlations - All cases

\begin{tabular}{|ll|c|c|c|}
\hline & & Salesperson trust & Product trust & Company trust \\
\hline Product trust & Pearson Correlation & .764 & & \\
& Sig. (2-tailed) & .000 & 270 & \\
& $\mathrm{~N}$ & 270 & .871 & \\
\hline Company trust & Pearson Correlation & .730 & .000 & \\
& Sig. (2-tailed) & .000 & 270 & -.470 \\
& $\mathrm{~N}$ & 270 & -.462 & .000 \\
\hline Relational behavior & Pearson Correlation & -.511 & .000 & 270 \\
& Sig. (2-tailed) & .000 & 270 & \\
\hline
\end{tabular}

Table 2

Correlations - Successful salespersons

\begin{tabular}{|ll|c|c|c|}
\hline \multicolumn{1}{|l}{} & Salesperson trust & Product trust & Company trust \\
\hline Product trust & Pearson Correlation & .742 & & \\
& Sig. (2-tailed) & .000 & & \\
& $\mathrm{~N}$ & 147 & .854 & \\
& Pearson Correlation & .728 & .000 & \\
& Sig. (2-tailed) & .000 & 147 & -.481 \\
& $\mathrm{~N}$ & 147 & -.460 & .000 \\
\hline Relational behavior & Pearson Correlation & -.511 & .000 & 147 \\
& Sig. (2-tailed) & .000 & 147 & \\
\hline
\end{tabular}

Table 3

Correlations - Unsuccessful salespersons

\begin{tabular}{|ll|c|c|c|}
\hline & & Salesperson trust & Product trust & Company trust \\
\cline { 2 - 4 } Product trust & Pearson Correlation & .749 & & \\
& Sig. (2-tailed) & .000 & & \\
& $\mathrm{~N}$ & 123 & .870 & \\
& Pearson Correlation & .698 & .000 & 123 \\
\hline Sig. (2-tailed) & .000 & -.408 & -.410 \\
& $\mathrm{~N}$ & 123 & .000 & .000 \\
& Pearson Correlation & -.448 & 123 & 123 \\
\hline
\end{tabular}

The results of the MANOVA test were significant for all dependent variables; see Table 7 in the appendix. Hypothesis 2 proposed that B2B buyers will rate Salesperson trust, product trust, company trust, and relational selling behavior significantly higher for Successful Salespersons than for Unsuccessful Salespersons. In the pairwise comparisons conducted as part of the MANOVA test, Table 4, Successful Salespersons were rated significantly higher by buyers for salesperson trust, product trust, relational behavior, and company trust ( $\mathrm{p}<.05)$, supporting 
Hypothesis 2. It is noted that the Successful salesperson was coded as 1 and the Unsuccessful salesperson was coded as 2 in the data file and that relational behavior is reverse coded. The findings for the three trust components are similar to the propositions from the Walker, Churchill, and Ford 1979 proposition that trust is an antecedent to other successful sales behaviors, and replicates similar findings for higher trust factor ratings by buyers for successful salespersons by Plank, Reid, and Pullins (1999) and Pullins, Reid, and Plank (2004). This finding also lends credence to a 20 year old study in which a successful sale was the outcome of trust by the buyer in the salesperson (Anderson and Narus 1984). This finding provides further support that relational behavior is an for a successful sale, whether or not the sales manager prefers a relational approach (as implied by Guenzi, 2003), and notwithstanding the age of the relationship between the salespersons and buyers (Nicholson, Compeau, and Sethi 2001). Similar to the correlation analysis findings in which the correlation coefficients for relational behavior were lower than those for the trust components, and although still significant, the mean difference between successful and unsuccessful salespersons' relational behavior was rated lower by buyers than any of the three trust components.

Table 4

Pairwise Comparisons for Successful and Unsuccessful Salesperson

\begin{tabular}{|l|l|l|c|c|c|}
\hline \multicolumn{1}{|c|}{ Dependent Variable } & \multicolumn{1}{|c|}{$\begin{array}{c}\text { (I) Successful or } \\
\text { Unsuccessful } \\
\text { Salesperson }\end{array}$} & $\begin{array}{c}\text { (J) Successful or } \\
\text { Unsuccessful } \\
\text { Salesperson }\end{array}$ & $\begin{array}{c}\text { Mean Difference } \\
\text { (I-J) }\end{array}$ & $\begin{array}{c}\text { Std. } \\
\text { Error }\end{array}$ & $\begin{array}{c}\text { Sig. } \\
\text { ST factor scores }\end{array}$ \\
\hline PT factor scores & Successful Salesperson & Unsuccessful Salesperson & $-.517^{*}$ & .106 & .000 \\
\hline Relational approach scores & Successful Salesperson & Unsuccessful Salesperson & $-.422^{*}$ & .114 & .000 \\
\hline CT factor scores & Successful Salesperson & Unsuccessful Salesperson & $.343^{*}$ & .114 & .003 \\
\hline
\end{tabular}

* significant at $\mathrm{p}<.05$

In a similar pairwise comparison to test hypothesis 3, Buyers of repeat purchase industrial products and services will prefer greater relational selling behavior from the salesperson than will buyers of one-time transaction industrial products and services, the mean for relational selling behavior was significantly greater for repeat purchases than for a one-time buy, where repeat purchases were coded 1 in the original data and one-time buy purchases were coded 0 (Table 5), supporting Hypothesis 3. This finding extends the research from the B2C studies and provides further support for Lusch's and Brown's 1996 findings relative to long-term orientation and greater relational behavior between the buyer and salesperson, that is that the greater the likelihood of a continuing supply requirement, the greater the preference for a relationship with the salesperson.

Table 5

Pairwise Comparisons for Repeatable Purchase and One Time Buy

\begin{tabular}{|c|c|c|c|c|c|}
\hline Dependent Variable & (I) Repeatable Purchase & (J) Repeatable Purchase & $\begin{array}{c}\text { Mean Difference } \\
\text { (I-J) }\end{array}$ & $\begin{array}{c}\text { Std. } \\
\text { Error }\end{array}$ & Sig.(a) \\
\hline Relational approach scores & Yes & No one time buy & $.435^{*}$ & .172 & .012 \\
\hline
\end{tabular}

* significant at $\mathrm{p}<.05$

Although hypothesis 4, The greater the percentage of team sales, the lower B2B buyers will rate Salesperson trust, product trust, company trust, and relational selling behavior, was supported, it was not consistently valid for the entire range of team selling percentages for all four dependent variables. Refer to Table 6 below and Table 7, Post Hoc tests, in the appendix. The clearest indicators are the buyers' perceptions of salesperson trust and relational behavior, for which there are no significant differences between 0 and $20 \%$ team selling but for which there are significant differences otherwise. Product trust is comparable to salesperson trust except that there are no significant differences in buyers' perceptions for team selling percentages of $40 \%$ and greater. There were only a few significant differences noted for company trust, again at the 0 and $20 \%$ team selling ranges, although again these supported the hypothesis generally. 
Table 6

Mean difference for team selling percentages

\begin{tabular}{|c|c|c|c|}
\hline Salesperson Trust & Product Trust & Relational Behavior & Company Trust \\
\hline $0>60 \%$ & $0>60 \%$ & $0>60 \%$ & $0>60 \%$ \\
\hline $0>80 \%$ & $0>80 \%$ & $0>80 \%$ & $20>60 \%$ \\
\hline $20>40 \%$ & $20>40 \%$ & $20>60 \%$ & \\
\hline $20>60 \%$ & $20>60 \%$ & $20>80 \%$ & \\
\hline $20>80 \%$ & $20>80 \%$ & $40>60 \%$ & \\
\hline $40>60 \%$ & & $40>80 \%$ & \\
\hline $40>80 \%$ & & & \\
\hline
\end{tabular}

Each of the above comparisons is significant at $\mathrm{p}<.05$

Hypothesis 5, There is a significant interaction between repeat purchases and team sales for B2B buyers on Salesperson trust, product trust, company trust, and relational selling behavior, is also supported; see Table 7 in the appendix. The interaction of a team selling environment with a repeat purchase condition for the buyer does result in higher mean scores for salesperson trust, product trust, relational behavior, and company trust. This lends additional credence to the concept that the greater interactions involved in team selling do result in closer association and higher buyer perceptions of trust and relational behavior with repeat purchasers (Moon and Armstrong 1994).

\section{MANAGERIAL IMPLICATIONS, LIMITATIONS AND DIRECTIONS FOR FURTHER RESEARCH}

This study was based on data from buyers in Western Europe. Given that every country has its own business and social cultures, the findings here may not be generalizable to other cultures, such as South America, the Middle East, or the Far East. There may also be underlying or hidden cultural biases and other buyer-seller dyad role expectations that this study did not predict. Relational behavior particularly may be accepted differently depending on the national culture (Ndubisi 2004).

Cause and effect relationships among the trust and relational behavior variables were not measured, and the study did not consider the directionality of trust and relational behavior and sales success. The study was also limited to the buyers of one company and its product lines and salespersons; thus the results were possibly as much a measure of the company, its products and salespersons than it was of the constructs generally. The results could differ among other industries or if a sample was drawn from respondents who measured salespersons from different companies or different products. Future studies could also consider these cause and effect linkages to more clearly measure the degree to which trust, relational behavior, and environmental conditions relate to, affect and are affected by sales success.

\section{AUTHOR INFORMATIO}

Richard A.L. Caldarola is an Assistant Professor with Troy University in Atlanta, Georgia, USA. He teaches graduate classes in marketing, strategy, research, and managerial accounting. His recent publications include a case study on client based consulting, an analysis of online pedagogy and student performance, and a study of the congruence of inertia and job embeddedness. His additional research interests include gender and cultural differences in selling behaviors, emotional intelligence and managerial performance, investor confidence related to the Sarbanes-Oxley Act of 2002, and the branding of higher education. Richard can be contacted at Troy University at rcaldarola@troy.edu.

\section{REFERENCES}

1. Agarwal, A. and R. Shankar, On-line Trust Building in E-enabled Supply Chain, Supply Chain Management, Vol. 83, No. 4, pp. 324-334, 2003.

2. Anderson, E. and B. Weitz, Determinants of Continuity in Conventional Industrial Channel Dyads, Marketing Science, Vol. 8, No. 3, pp. 310-23, 1989.

3. Anderson, J. C. and J. A. Narus, A Model of the Distributor's Perspective of Distributor-manufacturer Working Relationship, Journal of Marketing, Vol. 48, pp. 62-74, 1984. 
4. Bigne, E. and A. Blesa, Market Orientation Trust and Satisfaction in Dyadic Relationships: A Manufacturer-Retailer Analysis, International Journal of Retail and Distribution Management, Vol. 31, No. 11/12, pp. 574-590, 2003.

5. Bitner, M. J., Building Service Relationships: It's all About Promises, Journal of the Academy of Marketing Science, Vol. 23, No. 4, pp. 246-251, 1995.

6. Chandon, P., V. G. Morwitz, and W. J. Reinartz, The Short- and Long-Term Effects of Measuring Intent to Repurchase, Journal of Consumer Research, Vol. 31, No. 3, pp. 566-572, 2004.

7. Chow, S. and R. Holden, Toward an Understanding of Loyalty: The Moderating Role of Trust, Journal of Managerial Issues, Vol. 9, No. 3, pp. 275-298, 1997.

8. Crosby, L. A., K. R. Evans, and D. Cowles, Relationship Quality in Services Selling: An Interpersonal Influence Perspective, Journal of Marketing, Vol. 54, No. 3, pp. 68-81, 1990.

9. Doney, P. M. and J. P. Cannon, An Examination of the Nature of Trust in Buyer-Seller Relationships, Journal of Marketing, Vol. 61, No. 2, pp. 35-51, 1997.

10. Dubinsky, A. J., A Factor Analytic Study of the Personal Selling Process, Journal of Personal_Selling \& Sales Management, Vol. Fall/Winter, pp. 26-33, 1980.

11. Dubinsky, A. J. and W. Rudelius, Selling Techniques for Industrial Products and Services: Are They Different, Journal of Personal Selling \& Sales Management, Vol. Fall/Winter, pp. 65-75, 1980.

12. Dwyer, F. R., J. Hill, and W. Martin, An Empirical Investigation of Critical Success Factors in the Personal Selling Process for Homogenous Goods, Journal of Personal Selling \& Sales Management, Vol. 20, No. 3, pp. 152-160, 2000.

13. Dwyer, F. R., P. H. Schurr, and S. Oh, Developing Buyer-Seller Relationships, Journal of Marketing, Vol. 51, pp. 11-27, 1987.

14. Ekici, A. and R. Sohi, The role of Pre-Relational Trust in First Time Supplier Selection?, American Marketing Association. Conference Proceedings: 2000 AMA Winter Educators' Conference: Marketing Theory, Vol. 11, pp. 265-275, 2000. Retrieved March 22, 2005, from ABI/INFORM Complete database. (Document ID: 59216077).

15. Fitzgibbon, C. and L. White, The Role of Attitudinal Loyalty in the Development of Customer Relationship Management Strategy within Service Firms, Journal of Financial Services Marketing, Vol. 9, No. 3, pp. 214-230, 2005.

16. Foster, B. D. and J. W. Cadogan, Relationship Selling and Customer Loyalty: An Empirical Investigation, Marketing Intelligence and Planning, Vol. 18, No. 4, pp. 185-199, 2000.

17. Frankwick, G. L., S. S. Porter, and L. A. Crosby, Dynamics of Relationship Selling: A Longitudinal Examination of Changes in Salesperson-Customer Relationship Status, The Journal of Personal Selling \& Sales Management, Vol. 21, No. 2, pp. 135-146, 2001.

18. Ganesan, S., Determinants of Long-Term Orientation in Buyer-Seller Relationships, Journal of Marketing, Vol. 58, No. 2, pp. 1-19, 1994.

19. Gassenheimer, J. B. and C. Manolis, The Influence of Product Customization and Supplier Selection on Future Intentions: The Mediating Effects of Salesperson and Organizational Trust, Journal of Managerial Issues, Vol. 13, No. 4, pp. 418-435, 2001.

20. Guenzi, P., Antecedents and Consequences of a Firm's Selling Orientation, European Journal of Marketing, Vol. 37, No. 5/6, pp. 706-727, 2003.

21. Hite, R. E. and J. A. Bellizzi, Differences in the Importance of Selling Techniques Between Consumer and Industrial Salespeople, Journal of Personal Selling \& Sales Management, Vol. November, pp. 19-30, 1985.

22. Jones, E., A. L. Dixon, L. B. Chonko, and J. P. Cannon, Key Accounts and Team Selling: A Review, Framework, and Research Agenda, Journal of Personal Selling \& Sales Management, Vol. 25, No. 2, pp. 182-198, 2005.

23. Kim, B., M. Shi, and K. Srinivasan, Reward Programs and Tacit Collusion, Marketing Science, Vol. 20, No. 2, pp. 99-119, 2001.

24. Kumar, P., The Impact of Performance, Cost, and Competitive Considerations on the Relationship between Satisfaction and Repurchase Intent in Business Markets, Journal of Service Research, Vol. 5, No. 1, pp. 5568, 2002.

25. Lusch, R. F. and J. R. Brown, Interdependency, Contracting, and Relational Behavior in Marketing Channels, Journal of Marketing, Vol. 60, No. 4, pp. 19-38, 1996. 
26. Meyer-Waarden, L., The Effects of Loyalty Programs on Customer Lifetime Duration and Share of Wallet, Journal of Retailing, Vol. 83, No. 2, pp. 223-236, 2007.

27. Moon, M. A. and G. M. Armstrong, Selling Teams: A Conceptual Framework and Research Agenda, The Journal of Personal Selling \& Sales Management, Vol. 14, No. 1, pp. 17-30, 1994.

28. Moorman, C., G. Zaltman, and R. Deshpande, Relationships Between Providers and Users of Market Research: The Dynamics of Trust within and between Organizations, Journal of Marketing Research, Vol. 29, pp. 314-328, 1992.

29. Morgan, R. M. and S. D. Hunt, The Commitment-trust Theory of Relationship Marketing, Journal of Marketing, Vol. 58, pp. 20-38, 1994.

30. Ndubisi, N. O., Understanding the Salience of Cultural Dimensions on Relationships and Aftermaths, Cross Cultural Management, Vol. 11, No. 3, pp. 70-89, 2004.

31. Nicholson, C. Y., L. D. Compeau, and R. Sethi, The Role of Interpersonal Liking in Building Trust in Long-Term Channel Relationships, Academy of Marketing Science. Journal, Vol. 29, No. 1, pp. 3-15, 2001.

32. Nunnally, J. C., Psychometric Theory, McGraw-Hill, New York, 1967.

33. Parsons, A. L., What Determines Buyer-Seller Relationship Quality? An Investigation from the Buyer's Perspective, Journal of Supply Chain Management, Vol. 38, No. 2, pp. 4-12, 2002.

34. Patterson, P.G., A Contingency Model of Behavioural Intentions in a Services Context, Journal of Marketing, Vol. 38, No. 9/10, pp. 1304-1315, 2004.

35. Perry, M. L., C. L. Pearce, and H. P. Sims, Jr., Empowered Selling Teams: How Shared Leadership Can Contribute to Selling Team Outcomes, Journal of Personal Selling \& Sales Management, Vol. 19, No. 2, pp. 35-51, 1999.

36. Peterson, R. A., M. P. Cannito, and S. P. Brown, An Exploratory Investigation of Voice Characteristics and Selling Effectiveness, Journal of Personal Selling and Sales Management, Vol. 15, No. Winter, pp. 1-15, 1995.

37. Plank, R. E. and D. A. Reid, The Mediating Role of Sales Behaviors: An Alternate Perspective of Sales Performance and Effectiveness, Journal of Personal Selling and Sales Management, Vol. 14, No. 2, pp. 4356, 1994.

38. Plank, R. E., D. R. Reid, and E. B. Pullins, Perceived Trust in Business-to-Business Sales: A New Measure, The Journal of Personal Selling \& Sales Management, Vol. 19, No. 3, pp. 61-71, 1999.

39. Predmore, C. E. and J. G. Bonnice, Sales Success as Predicted by a Process Measure of Adaptability, Journal of Personal Selling and Sales Management, Vol. 14, No. Fall, pp. 55-63, 1994.

40. Pullins, E. B., D. R., Reid, and R. E. Plank, Gender Issues in Buyer-Seller Relationships: Does Gender Matter in Purchasing?, Journal of Supply Chain Management, Vol. 40, No. 3, pp. 40-48, 2004.

41. Raymond, M. A. and J. F. Tanner, Jr., Maintaining Customer Relationships in Direct Sales: Stimulating Repeat Purchase Behavior, The Journal of Personal Selling \& Sales Management, Vol. 14, No. 4, pp. 6776, 1994.

42. Reid, D. A., R. E. Plank, and A. Minton, Behaviors and Sales Performance: What Do Buyers Respond to in Sales Presentations, Journal of Marketing Management, Vol. 7, No. 1, pp. 1-13, 1996.

43. Sallee, A. and K. Flaherty, Enhancing Salesperson Trust: An Examination of Managerial Values, Empowerment, and the Moderating Influence of SBU Strategy, Journal of Personal Selling \& Sales Management, Vol. 23, No. 4, pp. 299-310, 2003.

44. Selnes, F., Antecedents and Consequences of Trust and Satisfaction in Buyer-Seller Relationships, European Journal of Marketing, Vol. 32, No. 3/4, pp. 305-322, 1998.

45. Skogland, I., and J. A. Siguaw, Are Your Satisfied Customers Loyal?, Cornell Hotel and Restaurant Administration Quarterly, Vol. 45, No. 3, pp. 221-234, 2004.

46. Spiro, R. L. and W. D. Perreault, Jr., Influence Use by Industrial Salesmen: Influence-Strategy Mixes and Situational Determinants, Journal of Business, Vol. 52, No. 3, pp. 435-455, 1979.

47. Tripp, C. and J. T. Drea, Selecting and Promoting Service Encounter Elements in Passenger Rail Transportation, The Journal of Services Marketing, Vol. 16, No. 5, pp. 432-450, 2002.

48. Whyte, R., Loyalty Marketing and Frequent Flyer Programmes: Attitudes and Attributes of Corporate Travelers, Journal of Vacation Marketing, Vol. 9, No. 1, pp. 17-34, 2002.

49. Whyte, R., Frequent Flyer Programmes: Is it a Relationship, or Do the Schemes Create Spurious Loyalty?, Journal of Targeting, Measurement and Analysis for Marketing, Vol. 12, No. 3, pp. 269-280, 2004. 
50. Wilson, D. T., An Integrated Model of Buyer-Seller Relationships, Journal of the Academy of Marketing Science, Vol. 23, No. 4, pp. 335-345, 1995.

51. Wong, A. and A. Sohal, An Examination of the Relationship between Trust, Commitment and Relationship Quality. International Journal of Retail \& Distribution Management, Vol. 30, No. 1, pp. 34-50, 2002.

52. Workman, J. P. Jr., C. Homburg, and O. Jensen, Intraorganizational Determinants of Key Account Management Effectiveness, Academy of Marketing Science. Journal, Vol. 31, No. 1, pp. 3-21, 2003.

53. Wright, R. F. and W. J. Lundstrom, Physicians' Perceptions of Pharmaceutical Sales Representatives: A Model for Analyzing the Customer Relationship, International Journal of Medical Marketing, Vol. 4, No. 1, pp. 29-38, 2004. 


\section{APPENDIX}

Table 7

General Linear Model

\begin{tabular}{|ll|c|c|}
\hline \multicolumn{1}{|c|}{ Between-Subjects Factors } \\
\hline Successful or Unsuccessful Salesperson & & Value Label & N \\
Repeatable Purchase & 1 & Successful Salesperson & 147 \\
& 2 & Unsuccessful Salesperson & 123 \\
\% of calls as team calls & 0 & No one time buy & 83 \\
& 1 & Yes & 187 \\
& 0 & 0 & 67 \\
& 1 & $20 \%$ & 103 \\
& 2 & $40 \%$ & 28 \\
& 4 & $60 \%$ & 21 \\
\end{tabular}

Tests of Between-Subjects Effects

\begin{tabular}{|c|c|c|c|c|c|c|}
\hline Source & Dependent Variable & $\begin{array}{c}\text { Type III Sum of } \\
\text { Squares }\end{array}$ & df & Mean Square & $\mathbf{F}$ & Sig. \\
\hline \multirow[t]{4}{*}{ Corrected Model } & ST factor scores & 82.429 (a) & 11 & 7.494 & 10.363 & .000 \\
\hline & PT factor scores & $51.990(\mathrm{~b})$ & 11 & 4.726 & 5.619 & .000 \\
\hline & Relational approach scores & $50.122(\mathrm{c})$ & 11 & 4.557 & 5.371 & .000 \\
\hline & CT factor scores & $50.678(d)$ & 11 & 4.607 & 5.444 & .000 \\
\hline \multirow[t]{4}{*}{ Intercept } & ST factor scores & 1.277 & 1 & 1.277 & 1.766 & .185 \\
\hline & PT factor scores & .506 & 1 & .506 & .602 & .439 \\
\hline & Relational approach scores & .043 & 1 & .043 & .051 & .821 \\
\hline & CT factor scores & 1.069 & 1 & 1.069 & 1.264 & .262 \\
\hline \multirow{4}{*}{ REPEAT $*$ TEAMSALE } & ST factor scores & 37.026 & 4 & 9.256 & 12.800 & .000 \\
\hline & PT factor scores & 21.331 & 4 & 5.333 & 6.340 & .000 \\
\hline & Relational approach scores & 18.663 & 4 & 4.666 & 5.500 & .000 \\
\hline & CT factor scores & 24.091 & 4 & 6.023 & 7.117 & .000 \\
\hline \multirow[t]{4}{*}{ SUCCESS } & ST factor scores & 17.319 & 1 & 17.319 & 23.950 & .000 \\
\hline & PT factor scores & 11.539 & 1 & 11.539 & 13.719 & .000 \\
\hline & Relational approach scores & 7.620 & 1 & 7.620 & 8.982 & .003 \\
\hline & CT factor scores & 10.769 & 1 & 10.769 & 12.726 & .000 \\
\hline \multirow[t]{4}{*}{ REPEAT } & ST factor scores & 3.346 & 1 & 3.346 & 4.627 & .032 \\
\hline & PT factor scores & .761 & 1 & .761 & .905 & .342 \\
\hline & Relational approach scores & 4.940 & 1 & 4.940 & 5.823 & .017 \\
\hline & CT factor scores & .266 & 1 & .266 & .314 & .576 \\
\hline \multirow[t]{4}{*}{ TEAMSALE } & ST factor scores & 27.259 & 5 & 5.452 & 7.539 & .000 \\
\hline & PT factor scores & 25.722 & 5 & 5.144 & 6.116 & .000 \\
\hline & Relational approach scores & 15.144 & 5 & 3.029 & 3.570 & .004 \\
\hline & CT factor scores & 22.785 & 5 & 4.557 & 5.385 & .000 \\
\hline \multirow[t]{4}{*}{ Error } & ST factor scores & 186.571 & 258 & .723 & & \\
\hline & PT factor scores & 217.010 & 258 & .841 & & \\
\hline & Relational approach scores & 218.878 & 258 & .848 & & \\
\hline & $\mathrm{CT}$ factor scores & 218.322 & 258 & .846 & & \\
\hline \multirow[t]{4}{*}{ Total } & ST factor scores & 269.000 & 270 & & & \\
\hline & PT factor scores & 269.000 & 270 & & & \\
\hline & Relational approach scores & 269.000 & 270 & & & \\
\hline & CT factor scores & 269.000 & 270 & & & \\
\hline \multirow[t]{4}{*}{ Corrected Total } & ST factor scores & 269.000 & 269 & & & \\
\hline & PT factor scores & 269.000 & 269 & & & \\
\hline & Relational approach scores & 269.000 & 269 & & & \\
\hline & CT factor scores & 269.000 & 269 & & & \\
\hline
\end{tabular}

a R Squared $=.306$ (Adjusted R Squared $=.277$ )

b R Squared $=.193$ (Adjusted R Squared $=.159$ )

c $\mathrm{R}$ Squared $=.186$ (Adjusted R Squared $=.152$ )

$\mathrm{d}$ R Squared $=.188$ (Adjusted R Squared $=.154$ ) 